Buana Sains Vol 17 No 1: 95 - 102

\title{
PENGARUH PEMBERIAN PUPUK PETROGANIK DAN KOMPOS PADA VERTISOL BEKAS GALIAN PEMBUATAN BATU BATA TERHADAP SERAPAN N SERTA PERTUMBUHAN TANAMAN JAGUNG
}

\author{
Bambang Siswanto dan Widowati \\ Fakultas Pertanian Universitas Tribhuwana Tunggadewi
}

\begin{abstract}
The low level of farms income from agricultural sector mainly happens in dry season had to inappropriate soil cultivation. The utilization of soil for brick ste manufacturing is one of this case. The excavation process occurs on top soil inflicting degradation of soil fertility. Soil in the impact of this condition has a problem in providing chemical element for the agriculture, especially the lack of $\mathrm{N}$. One of alternative attempts to increase the soil fertility in providing $\mathrm{N}$ on formerly brick ste excavation-soil is by supplying Petroganik fertilizer and compost. Petroganik and compost is an organic fertilizer containing N, P, K, the other nutrient, similar to the other organic fertilizers. The aims of the research are to determine the effect Petroganik fertilizer and compost application on $\mathrm{N}$ uptake and toward the growth of corn on former brick ste excavationsoil, and to know the chosen dosage which is resulting in growth and $\mathrm{N}$ uptake of corn. Research used is Random Block Design with 9 treatment and 3 replication. Dosage of treatment T0 : Control, Petroganik $(14,17,20,23) \mathrm{t} /$ ha and compost $(14,17,20,23)$ t/ha. Indicator plant was used Hybrid Corn BISI 2. The result of experiment showed that : 1. Significant effect in increasing uptake of $\mathrm{N}$ the corn. The treatment of Petroganik $17 \mathrm{t} / \mathrm{ha}(\mathrm{P} 2)$ increasing $145 \%$ and compost $14 \mathrm{t} / \mathrm{ha}$ (P2) increasing 93.8 $\%$, 2. Insignificant effect on plant growth (height, number of leaf) However, it gives significant effect on dry weight of the corn biomass. The treatment Petroganik $17 \mathrm{t} / \mathrm{ha}$ (P2), increases $101.45 \%, 3$. The application of Petroganik fertilizer is more effective in increasing the growth and $\mathrm{N}$ uptake of corn than that of compost since the application of $17 \mathrm{t} /$ ha of Petroganik has already increased the $\mathrm{N}$ uptake and growth of corn .
\end{abstract}

Keywords : Compost, Corn, Degradation, Petroganik, Vertisol

\section{PENDAHULUAN}

Tingkat pendapatan masyarakat yang kurang optimum pada sektor pertanian terutama pada saat musim kemarau menimbulkan berbagai bentuk penggunaan lahan yang tidak sesuai. Salah satu bentuk penggunaan lahan pertanian yang tidak sesuai adalah pemanfaatan sebagian lahan pertanian sebagai bahan baku guna pembuatan batu bata. Penggalian tanah terjadi secara terus menerus dalam jumlah yang sangat besar. Proses penggalian untuk pembuatan batu bata terjadi pada top soil, sehingga akan mendorong kemerosotan tingkat kesuburan tanah. Gejala fisik yang tampak jelas di tempat kejadian adalah hilangnya lapisan top soil, sehingga kemampuan tanah untuk berfungsi sebagai media tumbuh tanaman menjadi terbatas yang pada akhirnya ketidakstabilan ekosistem tidak dapat 
terhindarkan. Kondisi lahan bekas galian untuk pembuatan batu bata sangat memprihatinkan, lahan bekas galian guna pemanfaatan pembuatan batu bata sedalam 1 - 5 meter lebih dapat terlihat dengan jelas. Salah satu fungsi tanah adalah menyediakan kandungan unsur hara, karena ketersedian unsur hara sangat menentukan kesuburan tanah. Unsur hara sangat dibutuhkan untuk pertumbuhan tanaman, salah satu unsur hara yang paling banyak dibutuhkan oleh tanaman adalah unsur nitrogen karena berfungsi memperbaiki pertumbuhan vegetatif dan pembentukan protein tanaman. Pemberian bahan organik dapat secara langsung atau tidak langsung meningkatkan ketersediaan dan serapan $\mathrm{N}$ tanaman. Menurut Syukur and Indah (2006), fungsi bahan organik dalam tanah diantaranya menyediakan unsur $\mathrm{N}, \mathrm{P}, \mathrm{K}$ serta unsur-unsur mikro dan sebagai penyangga kation, sehingga unsur hara dalam tanah dapat dipertahankan.

Pupuk Petroganik merupakan salah satu bentuk bahan organik yang sudah diolah serta efektif dan efisien untuk diaplikasikan dilapangan. Pupuk Petroganik mempunyai keunggulan diantaranya kadar C-Organik tinggi, berbentuk butiran, aman, ramah lingkungan (bebas mikroba patogen) dan bebas dari biji-bijian/gulma. Kadar air pupuk petroganik tergolong rendah sehingga efisien dalam pengangkutan dan penyimpanan. Sedangkan kompos merupakan jenis pupuk organik dari bahan-bahan organik yang telah mengalami proses pelapukan karena adanya interaksi antar mikroorganisme (bakteri pendekomposisi) yang berperan di dalamnya Wahyono and Sahwan (1998). Pemberian pupuk organik adalah untuk memperbaiki fungsi tanah, secara fisik, kimia dan biologi. Berdasarkan uraian di atas maka perlu penelitian tentang pengaruh pemberian pupuk Petroganik dan kompos pada Vertisol bekas galian batu bata terhadap serapan $\mathrm{N}$ dan pertumbuhan pada tanaman jagung (sebagai tanaman indikator). Program ini juga merupakan suatu upaya mereklamasi lahan bekas galian batu bata yang sesuai dengan kondisi lingkungan dan sosial masyarakat sehingga nantinya dapat diadopsi oleh masyarakat.

\section{METODOLOGI}

Penelitian ini dilakukan di rumah kaca. Analisis dasar tanah dilaksanakan di Laboratorium Kimia dan Fisika Tanah, Fakultas Pertanian Universitas Brawijaya.. Waktu penelitian mulai bulan November 2013 sampai dengan bulan Mei 2014. Tanah diambil dari lahan bekas galian pembuatan batu bata yang sudah tidak digunakan lagi (kedalaman 1 $1.5 \mathrm{~m}$ dari top soil) yang berada di Desa Sraturejo, Kecamatan Baureno, Kabupaten Bojonegoro secara komposit pada kedalaman 0 - $20 \mathrm{~cm}$ (lapisan olah tanah Vertisol). Tanah yang telah diambil dari lahan kemudian dikering udarakan serta dihaluskan dan diayak lolos ayakan $2 \mathrm{~mm}$, selanjutnya ditimbang setara $8 \mathrm{~kg}$ tanah kering oven $(1$ polybag $=$ setara 8 $\mathrm{kg}$ tanah kering oven) dan dimasukkan kedalam polybag. Sebelum tanah tersebut diberi perlakuan, terlebih dahulu dilakukan analisa dasar. Pupuk organik yang digunakan adalah pupuk Petroganik dan kompos (sampah kota). Tanaman indikator yang digunakan adalah jagung hibrida BISI-2. Penelitian ini menggunakan Rancangan Acak Lengkap (RAL) dengan 9 perlakuan dosis (Tabel 1). Setiap perlakuan dilakukan ulangan sebanyak 3 kali, dengan demikian terdapat 27 polybag perlakuan. 
B. Siswanto dan Widowati / Buana Sains Vol 17 No 1: 95 - 102

Tabel 1. Perlakuan pemberian dosis pupuk organik.

\begin{tabular}{ccc}
\hline No & Perlakuan & Dosis \\
\hline 1 & T0 & Kontrol (tanpa pemberian pupuk) \\
2 & P1 & Tanah + Pupuk Petroganik $14 \mathrm{t} / \mathrm{ha}$ \\
3 & P2 & Tanah + Pupuk Petroganik $17 \mathrm{t} / \mathrm{ha}$ \\
4 & P3 & Tanah + Pupuk Petroganik $20 \mathrm{t} / \mathrm{ha}$ \\
5 & P4 & Tanah + Pupuk Petroganik $23 \mathrm{t} / \mathrm{ha}$ \\
6 & K1 & Tanah + Kompos $14 \mathrm{t} / \mathrm{ha}$ \\
7 & K2 & Tanah + Kompos $17 \mathrm{t} / \mathrm{ha}$ \\
8 & K3 & Tanah + Kompos $20 \mathrm{t} / \mathrm{ha}$ \\
9 & K4 & Tanah + Kompos $23 \mathrm{t} / \mathrm{ha}$ \\
\hline
\end{tabular}

Keterangan $*: \mathrm{P}=$ Pupuk petroganik $; \mathrm{K}=$ Kompos

Pemupukan anorganik sebagai pupuk dasar diberikan dengan dosis pemupukan tanaman jagung yang dianjurkan yaitu SP18 $150 \mathrm{~kg} / \mathrm{ha}$ dan $\mathrm{KCl} 75 \mathrm{~kg} / \mathrm{ha}$ (PT. Petrokimia). Pupuk $\mathrm{KCl}$ dan SP18 diberikan pada saat tanam sebagai pupuk dasar. Untuk Petroganik dan kompos diberikan satu kali yaitu pada saat tanam. Pengamatan dilakukan terhadap pertumbuhan yakni tinggi tanaman diukur dari permukaan tanah sampai titik tumbuh tanaman (bagian tanaman yang paling tinggi). Jumlah daun dihitung dari seluruh daun yang membuka sempurna dan tidak kering. Pengamatan jumlah daun dan tinggi tanaman dilakukan pada saat 2 MST, 4 MST, 6 MST. Sedang berat kering tanaman yang diperoleh dengan cara menimbang seluruh bagian tanaman di atas tanah setelah di oven selama $2 \times 24$ jam pada suhu $65^{\circ} \mathrm{C}$. Hasil perhitungan parameter dianalisis dengan menggunakan analisis sidik ragam atau uji $\mathrm{F}$ dengan taraf $5 \%$, dilanjutkan uji Duncan $5 \%$. Kemudian untuk mengetahui keeratan hubungan antar parameter pengamatan dilakukan uji korelasi.

\section{HASIL DAN PEMBAHASAN}

\section{Serapan N Tanaman}

Hasil penelitian diketahui bahwa tingkat serapan nitrogen pada tanaman jagung tertinggi pada perlakuan kompos $23 \mathrm{t} / \mathrm{ha}$
(K4) sebesar $0.220 \mathrm{~g} /$ tanaman sedang pada perlakuan Petroganik $17 \mathrm{t} / \mathrm{ha}$ (P2) sebesar $0.216 \mathrm{~g} /$ tanaman (Tabel 2). Apabila dilihat dari nilai kedua hasil serapan tersebut, maka pemberian pupuk organik Petroganik dapat dikembangkan dari pada penggunaan kompos karena dengan pemberian Petroganik dosis 17 t/ha sudah dapat meningkatkan nilai serapan $\mathrm{N}$ pada tanaman jagung, dalam hal ini penggunaan Petroganik menjadi lebih murah. Hal ini dapat dilihat dari harga pupuk setiap kilogram, harga pupuk Petroganik lebih murah dari pada penggunaan kompos karena pupuk Petroganik mendapat subsidi dari pemerintah, yakni harga perkilo hanya sebesar Rp 500,- dan selisih harga antara Petroganik dengan kompos adalah Rp 14.500.000,- Hasil analisis ragam serapan $\mathrm{N}$ pada tanaman jagung, diketahui bahwa terdapat perbedaan yang nyata antara perlakuan penggunaan pupuk Petroganik dan kompos. Nilai rerata tertinggi perlakuan Petroganik adalah penggunaan dosis 17 t/ha (P2) sebesar 0.216 $\mathrm{g} /$ tanaman meningkat $145 \%$ dari kontrol dan pada perlakuan kompos adalah penggunaan dosis $23 \mathrm{t} / \mathrm{ha}$ (K4) sebesar $0.220 \mathrm{~g} /$ tanaman meningkat 150 $\%$ dari kontrol. Perlakuan dengan nilai rerata serapan $\mathrm{N}$ tanaman jagung terendah yaitu perlakuan kontrol (T0) sebesar $0.088 \mathrm{~g} / \tan a m a n$ (Tabel 2). 
Tabel 2. Pengaruh Petroganik dan kompos terhadap serapan N tanaman jagung

\begin{tabular}{|c|c|c|c|}
\hline \multirow[b]{2}{*}{ No } & \multirow[b]{2}{*}{ Perlakuan } & \multicolumn{2}{|c|}{ Waktu pengamatan (6 MST) } \\
\hline & & (g/tanaman) & $\begin{array}{c}\text { Perubahan } \\
(\%)\end{array}$ \\
\hline 1 & Kontrol (tanpa pemberian pupuk) & $0.08 \mathrm{a}$ & 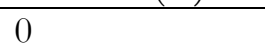 \\
\hline 2 & Tanah + Pupuk Petroganik $14 \mathrm{t} / \mathrm{ha}$ & $0.19 \mathrm{bcd}$ & 130 \\
\hline 3 & Tanah + Pupuk Petroganik $17 \mathrm{t} / \mathrm{ha}$ & $0.22 \mathrm{~d}$ & 145 \\
\hline 4 & Tanah + Pupuk Petroganik $20 \mathrm{t} / \mathrm{ha}$ & $0.15 \mathrm{~b}$ & 70 \\
\hline 5 & Tanah + Pupuk Petroganik $23 \mathrm{t} / \mathrm{ha}$ & $0.20 \mathrm{~cd}$ & 127 \\
\hline 6 & Tanah + Kompos $14 \mathrm{t} / \mathrm{ha}$ & $0.17 \mathrm{bc}$ & 93.18 \\
\hline 7 & Tanah + Kompos $17 \mathrm{t} / \mathrm{ha}$ & $0.09 \mathrm{a}$ & 3.41 \\
\hline 8 & Tanah + Kompos $20 \mathrm{t} / \mathrm{ha}$ & $0.09 \mathrm{a}$ & 5.68 \\
\hline 9 & Tanah + Kompos $23 \mathrm{t} / \mathrm{ha}$ & $0.22 \mathrm{~d}$ & 150 \\
\hline
\end{tabular}

Keterangan : Angka didampingi huruf yang sama menunjukkan tidak berbeda nyata pada Uji Duncan taraf $5 \%$.

Pada Tabel 2, terlihat bahwa perlakuan Petroganik dosis 17 t/ha (P2) mempunyai nilai serapan $\mathrm{N}$ yang tertinggi dibanding dengan perlakuan $\mathrm{P} 1$, P3 dan P4. Hal ini berarti perlakuan Petroganik dosis $17 \mathrm{t} /$ ha dimungkinkan adalah dosis yang optimum bagi tanaman. Sedangkan pada dosis yang di atasnya akan semakin menurunkan serapan pada tanaman. Karena pemberian pupuk dalam dosis yang berlebihan dapat berpengaruh jelek pada tanaman. Pada perlakuan penggunaan pupuk kompos berkebalikan dengan perlakuan Petroganik, semakin tinggi dosis kompos mempunyai nilai serapan tinggi. Perlakuan kompos dosis $23 \mathrm{t} / \mathrm{ha}$ mempunyai nilai serapan $\mathrm{N}$ yang tertinggi dibanding dengan perlakuan $\mathrm{K} 1$, $\mathrm{K} 2$ dan K3. Besarnya serapan $\mathrm{N}$ pada tanaman tidak hanya dipengaruhi oleh besar kecilnya nitrogen mineral, tapi juga harus sesuai dengan waktu tanaman membutuhkannya. Jadi diperlukan adanya keseimbangan antara ketersediaan unsur hara dalam tanah dengan waktu tanaman membutuhkan unsur hara tersebut Halliday and Trenkel (1992).

Pertumbuban Tanaman

Dari hasil penelitian diketahui bahwa bobot kering tanaman jagung tertinggi adalah pada perlakuan kompos $23 \mathrm{t} / \mathrm{ha}$
(K4) sebesar $16.52 \mathrm{~g}$ (Tabel 3). Apabila dilihat dari nilai kedua hasil bobot kering tanaman tersebut, mempunyai nilai yang hampir sama dengan nilai serapan $\mathrm{N}$ pada tanaman. Pada bobot kering tanaman mempunyai perbedaan yang lebih nyata peningkatan antara Petroganik dengan kompos. Pada perlakuan Petroganik $17 \mathrm{t} / \mathrm{ha}$ (P2) tingkat perubahannya sebesar $101.5 \%$ dari kontrol sedangkan kompos $23 \mathrm{t} / \mathrm{ha}$ sebesar $138.38 \%$. Apabila dilihat dari nilai persentase perubahan pemberian Petroganik lebih rendah dari pada kompos, tetapi apabila dilihat dari harga jual produksi pemberian Petroganik lebih murah untuk dikembangkan karena selisih harga pupuk setiap kilogram sebesar Rp 500,-.

Pada pertumbuhan tinggi dan jumlah daun tanaman tidak terjadi perbedaan yang nyata pada setiap perlakuan (Tabel 6 dan 7). Apabila dilihat dari nilai tinggi tanaman dan jumlah daun dapat disimpulkan bahwa pemberian Petroganik dan kompos tidak berbeda dalam meningkatakan tinggi tanaman dan jumlah daun. Dalam penentuan dosis pilihan berdasarkan tingkat pertumbuhan (bobot kering, tinggi dan jumlah daun) tanaman dilakukan analisis statistik pada hasil rata-rata perlakuan Petroganik dan kompos. 


\section{Bobot Kering Tanaman Jagung}

Dari hasil analisis ragam bobot kering tanaman jagung, diketahui bahwa terdapat perbedaan yang nyata pada perlakuan Petroganik dan kompos. Nilai rerata tertinggi perlakuan Petroganik adalah perlakuan Petroganik dosis 17 t/ha (P2) sebesar $13.97 \mathrm{~g}$ meningkat
$101.5 \%$ dari kontrol dan pada perlakuan kompos adalah perlakuan kompos dosis $23 \mathrm{t} / \mathrm{ha}(\mathrm{K} 4)$ sebesar $16.52 \mathrm{~g}$ meningkat $138 \%$ dari kontrol. Perlakuan dengan nilai rerata bobot kering tanaman jagung terendah yaitu perlakuan kontrol (T0) sebesar $6.93 \mathrm{~g}$ (Tabel 5).

Tabel 3. Pengaruh Petroganik dan kompos terhadap bobot kering tanaman jagung pada 6 MST

\begin{tabular}{llll}
\hline No & Perlakuan & \multicolumn{1}{c}{ Pobot kering (gram) } & \multicolumn{1}{c}{ Perubahan (\%) } \\
\cline { 3 - 4 } & & $6.93 \mathrm{a}$ & 0 \\
2 & Kontrol (tanpa pemberian pupuk) & $12.09 \mathrm{~cd}$ & 74.45 \\
2 & Tanah + Pupuk Petroganik 14 t/ha & $13.97 \mathrm{~d}$ & 101.50 \\
3 & Tanah + Pupuk Petroganik 17 t/ha & $7.88 \mathrm{a}$ & 13.70 \\
4 & Tanah + Pupuk Petroganik 20 t/ha & $10.16 \mathrm{bc}$ & 46.61 \\
5 & Tanah + Pupuk Petroganik 23 t/ha & $9.15 \mathrm{ab}$ & 32.03 \\
6 & Tanah + Kompos 14 t/ha & $10.25 \mathrm{bc}$ & 47.90 \\
7 & Tanah + Kompos 17 t/ha & $8.82 \mathrm{ab}$ & 27.27 \\
8 & Tanah + Kompos 20 t/ha & $16.52 \mathrm{e}$ & 138.38 \\
9 & Tanah + Kompos 23 t/ha &
\end{tabular}

Keterangan : Angka yang didampingi huruf yang sama menunjukkan tidak berbeda nyata pada Uji Duncan taraf $5 \%$.

Pada Tabel 5, dapat dilihat bahwa perlakuan Petroganik dosis $17 \mathrm{t} / \mathrm{ha}$ (P2) mempunyai nilai bobot kering tanaman yang tertinggi dibanding dengan perlakuan P1, P3 dan P4. Sedangkan perlakuan kompos dosis 23 t/ha mempunyai bobot kering tanaman yang tertinggi dibanding dengan perlakuan K1, K2 dan K3. Hal ini disebabkan semakin tinggi serapan $\mathrm{N}$ akan dapat meningkatkan bobot kering tanaman karena jumlah $\mathrm{N}$ yang dapat diserap berpengaruh terhadap kandungan protein sehingga berpengaruh terhadap pertumbuhan sel - sel pada tanaman. Peningkatan nilai persentase kadar nitrogen akan diikuti dengan peningkatan kadar protein kasar sebesar $6.25 \mathrm{~g}$.

Tanaman jagung menyerap nitrogen dalam bentuk ion nitrat dan amonium. Nitrogen adalah komponen utama dari berbagai substansi penting di dalam tanaman. Nitrogen digunakan untuk membentuk senyawa penting seperti klorofil, asam nukleat dan enzim Hairiah et al. (2000) Tanaman jagung menyerap nitrogen dalam bentuk ion nitrat dan amonium. Nitrogen adalah komponen utama dari berbagai substansi penting di dalam tanaman. Nitrogen digunakan untuk membentuk senyawa penting seperti klorofil, asam nukleat dan enzim. Apabila senyawa seperti klorofil terbentuk maka akan memudahkan tanaman untuk melakukan proses fotosintesis. Sehingga hasilnya akan ditranslokasikan ke organ vegetatif tanaman untuk membentuk organ baru seperti daun maupun menambah tinggi tanaman. Seiring dengan bertambah tinggi dan banyaknya jumlah daun jagung juga akan meningkatkan bobot kering jagung. Menurut Nuraini and Nanang (2003), salah satu fungsi unsur $\mathrm{N}$ dalam tanaman adalah merangsang aktivitas meristem dengan semakin meningkatnya jumlah $\mathrm{N}$ yang diserap oleh tanaman, maka jaringan meristematik pada titik 
tumbuh batang semakin aktif. Titik tumbuh batang semakin aktif menyebabkan semakin banyak ruas batang yang terbentuk, sehingga akan tumbuh tinggi.

\section{Tinggi Tanaman}

Pertumbuhan tanaman jagung dapat ditunjukkan oleh tinggi tanaman dan jumlah daun. Pengukuran terhadap tinggi tanaman dan jumlah daun dilakukan pada 2, 4 dan 6 MST. Tinggi tanaman 2, 4 dan 6 MST menunjukkan hasil yang tidak berbeda nyata.

Adanya perlakuan pemberian

Petroganik dan kompos dapat meningkatkan tinggi tanaman jagung bila dibandingkan dengan kontrol. Perlakuan kompos 14 t/ha (K1) memiliki nilai rerata tinggi tanaman yang tertinggi pada 2 MST dan kompos $17 \mathrm{t} / \mathrm{ha}$ (K2) memiliki nilai rerata tinggi tanaman yang tertinggi pada 4 sebesar $51 \mathrm{~cm}$ dengan peningkatan $13.33 \%$ dari kontrol dan perlakuan Petroganik 14 t/ha (P2) memiliki nilai sebesar $58.75 \mathrm{~cm}$ dengan peningkatan $17.03 \%$. Sedangkan nilai rerata terendah berturut-turut 2, 4 dan 6 MST adalah perlakuan Petroganik dosis $17 \mathrm{t} /$ ha sebesar $18.3 \mathrm{~cm}$ dan Kontrol (T0) sebesar $45 \mathrm{~cm}$ dan $50.2 \mathrm{~cm}$ (Tabel 4).

Tabel 4. Pengaruh Petroganik dan kompos terhadap tinggi tanaman jagung pada beberapa umur tanaman

\begin{tabular}{lccccccc}
\hline Perlakuan & \multicolumn{7}{c}{ Tinggi tanaman $(\mathrm{cm})$} \\
\cline { 2 - 8 } & $2 \mathrm{mst}$ & $\begin{array}{c}\text { Perubahan } \\
(\%)\end{array}$ & $4 \mathrm{mst}$ & $\begin{array}{c}\text { Perubahan } \\
(\%)\end{array}$ & $6 \mathrm{mst}$ & $\begin{array}{c}\text { Perubahan } \\
(\%)\end{array}$ \\
\hline T0 & $18.83 \mathrm{a}$ & 0 & $45.00 \mathrm{a}$ & 0 & $50.20 \mathrm{a}$ & 0 \\
P1 & $24.50 \mathrm{a}$ & 30.11 & $46.00 \mathrm{a}$ & 2.22 & 55.33 & $\mathrm{abc}$ & 10.21 \\
P2 & $18.30 \mathrm{a}$ & -2.65 & $47.33 \mathrm{a}$ & 5.17 & $58.75 \mathrm{c}$ & 17.03 \\
P3 & $21.16 \mathrm{a}$ & 12.37 & $46.00 \mathrm{a}$ & 2.22 & $52.00 \mathrm{ab}$ & 3.90 \\
P4 & $24.16 \mathrm{a}$ & 28.51 & $45.33 \mathrm{a}$ & 0.73 & $54.33 \mathrm{abc}$ & 8.22 \\
K1 & $25.16 \mathrm{a}$ & 33.82 & $48.66 \mathrm{a}$ & 8.13 & 55.67 & $\mathrm{abc}$ & 10.89 \\
K2 & $23.83 \mathrm{a}$ & 22.50 & $51.00 \mathrm{a}$ & 13.33 & $51.33 \mathrm{ab}$ & 2.25 \\
K3 & $22.75 \mathrm{a}$ & 21.01 & $46.00 \mathrm{a}$ & 2.22 & $57.50 \mathrm{bc}$ & 14.54 \\
K4 & $25.00 \mathrm{a}$ & 32.98 & $49.00 \mathrm{a}$ & 8.88 & $54.33 \mathrm{abc}$ & 8.22 \\
\hline
\end{tabular}

Keterangan : Angka yang didampingi huruf yang sama menunjukkan tidak berbeda nyata pada Uji Duncan taraf $5 \%$. T0 : Kontrol, P1 : Petroganik 14 t/ha, P2 : Petroganik 17 t/ha, P3 : Petroganik 20 t/ha, P4 : Petroganik 23 t/ha, K1 :kompos 14 t/ha, K2 : kompos 17 t/ha, K3 : kompos 20 t/ha, K4 : kompos 23 t/ha

Pada 2 MST tidak berbeda nyata diduga tanaman jagung masih terlalu muda sehingga penyerapan unsur hara masih belum optimal dan masih memanfaatkan cadangan makanan yang berada pada endosperma biji, sehingga pertumbuhan jagung relatif sama. Menurut Kanmegne et al. (1995) bahwa nitrogen merupakan unsur yang mempengaruhi pertumbuhan tanaman dan juga penyusun protein dan diperlukan dalam jumlah relatif banyak.
Peningkatan kadar nitrogen akan diikuti oleh peningkatan kadar protein pada tanaman. Kadar protein akan berpengaruh terhadap pertumbuhan sel pada tanaman dan kadar protein diperoleh dari persentase kadar nitrogen dikali 6.25 g. Nitrogen mempengaruhi pertumbuhan tanaman dengan melalui cara-cara sebagai berikut : a) meningkatkan pertumbuhan daun dan batang, b) meningkatkan kandungan protein (Syarifudin K, 1990). 


\section{Jumlab Daun Tanaman}

Pada parameter pengamatan jumlah daun, menunjukkan tidak adanya perbedaan yang nyata untuk semua perlakuan sampai waktu 6 MST Secara umum pemberian Petroganik dan kompos dapat meningkatkan jumlah daun tanaman jagung bila dibandingkan dengan kontrol dari 4 sampai 6 MST.
Hasil pengamatan dapat dilihat pada Gambar 2.

Nilai rerata tertinggi 4 dan 6 MST berturut-turut adalah perlakuan Petroganik dosis $17 \mathrm{t} / \mathrm{ha}$ (P2) sebesar 6.33 helai dan 7.33 helai. Sedangkan nilai rerata terendah berturut-turut dari pengamatan 2, 4 dan 6 MST adalah perlakuan Petroganik dosis 17 t/ha (P2), dan T0 sebesar 3.6 helai, 5.00 helai dan 6.33 helai (Tabel 5).

Tabel 5. Pengaruh Petroganik dan kompos terhadap jumlah daun tanaman jagung Pada beberapa umur tanaman

\begin{tabular}{lccclccc}
\hline Perlakuan & \multicolumn{7}{c}{ Jumlah daun } \\
\cline { 2 - 8 } & $2 \mathrm{mst}$ & $\begin{array}{c}\text { Perubahan } \\
(\%)\end{array}$ & $4 \mathrm{mst}$ & $\begin{array}{c}\text { Perubahan } \\
(\%)\end{array}$ & $6 \mathrm{mst}$ & $\begin{array}{c}\text { Perubahan } \\
(\%)\end{array}$ \\
\hline T0 & $3.60 \mathrm{a}$ & 0 & 5.00 & $\mathrm{a}$ & 0 & $6.33 \mathrm{a}$ & 0 \\
P1 & $4.00 \mathrm{a}$ & 11.11 & 6.00 & $\mathrm{ab}$ & 20.00 & $6.67 \mathrm{a}$ & 5.37 \\
P2 & $3.30 \mathrm{a}$ & -8.30 & 6.33 & $\mathrm{~b}$ & 26.60 & $7.00 \mathrm{a}$ & 10.58 \\
P3 & $4.00 \mathrm{a}$ & 11.11 & 6.00 & $\mathrm{ab}$ & 20.00 & $7.00 \mathrm{a}$ & 10.58 \\
P4 & $4.00 \mathrm{a}$ & 11.11 & 6.00 & $\mathrm{ab}$ & 20.00 & $7.00 \mathrm{a}$ & 10.58 \\
K1 & $4.00 \mathrm{a}$ & 11.11 & 5.67 & $\mathrm{ab}$ & 13.40 & $6.67 \mathrm{a}$ & 5.37 \\
K2 & $4.00 \mathrm{a}$ & 11.11 & 5.33 & $\mathrm{ab}$ & 6.60 & $7.33 \mathrm{a}$ & 15.79 \\
K3 & $4.00 \mathrm{a}$ & 11.11 & 5.66 & $\mathrm{ab}$ & 13.20 & $6.67 \mathrm{a}$ & 5.37 \\
K4 & $4.00 \mathrm{a}$ & 11.11 & 6.00 & $\mathrm{ab}$ & 20.00 & $7.00 \mathrm{a}$ & 10.58 \\
\hline
\end{tabular}

Keterangan : Angka yang didampingi huruf yang sama menunjukkan tidak berbeda nyata pada Uji Duncan taraf $5 \%$. T0 : Kontrol, P1 : Petroganik 14 t/ha, P2: Petroganik 17 t/ha, P3 : Petroganik 20 t/ha, P4 : Petroganik 23 t/ha, K1 :kompos 14 t/ha, K2: kompos 17 t/ha, K3: kompos 20 t/ha, K4: kompos 23 t/ha

Tidak adanya beda yang nyata pada parameter jumlah daun disini karena diduga hasil serapan $\mathrm{N}$ tanaman lebih berfungsi untuk pertumbuhan batang (bobot kering) dan tinggi tanaman karena dari hubungan korelasi antara kadar $\mathrm{N}$ dengan bobot kering $\left(r=0.622^{* *}\right)$ dan tinggi tanaman menunjukkan perbedaan nyata.

\section{Hubungan Antara Kadar N dengan Pertumbuhan Tanaman Jagung}

Dari hasil analisis korelasi didapatkan korelasi positif antara kadar $\mathrm{N}$ dengan bobot kering tanaman $\left(\mathrm{r}=0.622^{* *}\right)$, sedangkan pada tinggi dan jumlah tidak berkolesi terhadap kadar N. Apabila dilihat dari nilai korelasi antara bobot kering tanaman dengan kadar $\mathrm{N}$ yang erat hubungannya menandakan bahwa bobot kering tanaman sangat dipengaruhi oleh kadar $\mathrm{N}$ tanaman, karena $\mathrm{N}$ pada tanaman berfungsi sebagai pembentuk protein dimana peningkatan persentase kadar $\mathrm{N}$ akan diikuti dengan $6.25 \mathrm{~g}$ kadar protein kasar, sehingga jumlah protein pada tanaman berekuivalen terhadap bobot kering tanaman. Apabila senyawa seperti klorofil terbentuk maka akan memudahkan tanaman untuk melakukan proses fotosintesis. Hasil dari fotosintesis akan ditranslokasikan ke organ vegetatif tanaman untuk membentuk organ baru seperti daun maupun menambah tinggi tanaman. Seiring dengan bertambah tinggi dan banyaknya jumlah daun jagung juga akan meningkatkan bobot kering jagung. Hal ini sejalan dengan pendapat 
Nuraini and Danang (2003) bahwa nitrogen merupakan unsur yang mempengaruhi pertumbuhan tanaman dan juga penyusun protein dan diperlukan dalam jumlah relatif banyak. Unsur nitrogen bagi tanaman dapat membantu proses fotosintesis karena memberi warna hijau pada daun atau klorofil. Hasil fotosintesis dapat didestribusikan kesemua bagian tanaman untuk pertumbuhan termasuk tinggi tanaman. Tanaman akan menjadi kerdil dan pertumbuhan perakaran mengalami penghancuran bila kekurangan nitrogen.

Korelasi antara kadar $\mathrm{N}$ dengan jumlah daun menunjukkan hasil yang tidak berbeda nyata $(r=0.049)$, hal ini diduga hasil serapan $\mathrm{N}$ tanaman lebih berfungsi untuk pertumbuhan batang (bobot kering) dan tinggi tanaman, karena dari hubungan korelasi antara kadar $\mathrm{N}$ dengan bobot kering dan tinggi tanaman menunjukkan keeratan hubungan. Proses metabolisme tanaman pada massa vegetatif memerlukan banyak unsur hara terutama nitrogen untuk pertumbuhan sel-sel tanaman.

\section{KESIMPULAN}

Berdasarkan hasil penelitian dapat diperoleh kesimpulan sebagai berikut:

1. Pemberian pupuk Petroganik dan kompos pada Vertisol bekas galian pembuatan batu bata secara umum dapat memberikan pengaruh dalam meningkatkan serapan $\mathrm{N}$ tanaman. Perlakuan Petroganik 17 t/ha (P2) berpengaruh paling baik dalam meningkatkan serapan $\mathrm{N}$ tanaman (meningkat $145 \%$ dari kontrol).

2. Pemberian pupuk Petroganik dan kompos pada Vertisol bekas galian pembuatan batu bata tidak berpengaruh terhadap parameter pertumbuhan tanaman (tinggi, jumlah daun), namun demikian memberikan pengaruh terhadap bobot kering tanaman.

\section{DAFTAR PUSTAKA}

Hairiah, K., Widianto, Sri R. U, Didik, S., Sunaryo, S. M Sitompul, Betha L, Rachmat, M., Van Noordjwik, $M$ dan Cadisch, G. 2000. Pengelolaan Tanah Masam Secara Biologi : Refleksi Pengalaman Dari Lampung Utara. ICRAF SEA. Bogor

Halliday, D.J. and M.E. Trenkel. 1992. IFA World Fertilizer Use Manual. International Fertilizer Industry Association, Paris.

Karama, Syarifuddin. 1990. Penggunaan pupuk organik dalam produksi pertanian. Puslitbangtan. Bogor

Kanmegne, J., B. Dugma., J. Hentat N. O. Isrimah. 1995. Decomposition and Nutrient Release From Residue of Calliandra calathyrsas, Alcharnea cardifolia Pennisetum Purpureum dan Chromolama Odorata. Hal 29 - 36. In Neeteson, J.J. dan J. Henrot. The Rule of Plant Residue in Soil Management for Food Production in The Humid Tropic. Final Report PGIS Project NG/91/852. Haren

Nuraini, Y. Dan Nanang, S. A. 2003. Pengaruh Pupuk Hayati dan Bahan Organik Terhadap Sifat Kimia dan Biologi Tanah Serta Pertumbuhan dan Produksi Tanaman Jagung (Zea mays L.). Habitat Vol XIV No.3 : 139-145.

Setiyo, Y. 2007. Pengembangan Model Simulasi Proses Pengomposan Sampah Organik Perkotaan. Disertasi S-3. IPB. Bogor.

Syukur, A dan Indah N,M. 2006. Kajian Pengaruh Pemberian macam Pupuk Organik Terhadap pertumbuhan dan Hasil Tanaman Jahe di Inceptisol, Karanganyar. Jurnal Ilmu Tanah dan Lingkugan vol 6 (2) (2006) p: 124-131 http://soil.faperta.ugm.ac.id/jitl/6.2\%20 124-131\%20syukur.pdf, diakses 20 agustus 2008.

Wahyono S dan Sahwan FL. 1998. Solid waste composting trend and projects. $J$ Biocycle 38(1):64-68. 